\title{
Postcolonialism and the Politics of Resistance in Ngugi Thiond'o's Wizard of the Crow
}

\author{
*Ugwuanyi 'Dele Maxwell \\ http://dx.doi.org/10.4314/ujah.v15i1.4
}

\section{Absract}

This paper makes an attempt at investigating the dialectics involved in the politics of resistance against Imperialism in Africa. The paper uses the Ngugi wa Thiong'o's novel, Wizard of the Crow as its textual reference. It is pertinent to note that many African writers have written on the dialectics that has propelled the continent forward or otherwise but none has actually captured the kind of resistance to neo-colonialism like the writer used for this research analysis. The paper looks at the reasons that have conditioned African countries to remain under-developed despite the promises at independence. It also looks at both the internal and external intricacies that have been at play in the struggle for the soul of post-independence Africa. The paper opines that writers in Africa should use their writings to awake the consciousness of the masses to the reality of their circumstances and to develop mechanisms to arrest them. The paper goes further to recommend serious resistance measures against the enemies of the people which are largely members of the political class who have collaborated with the West to continue the pauperization of the African masses. The paper concludes that Africa countries should stop the over reliance on the West for aids and focus on the real development needs of their people. 


\section{Introduction}

The ancestry of the concept of post-colonialism can be traced to Frantz Fanon's The Wretched of the Earth, published in French in 1961 and voicing what might be called 'cultural resistance' to France's African Empire. Fanon argued that the first step for colonized people in finding a voice and an identity is to reclaim their own past. This is so because, for centuries the European colonizing power will have devalued the continent's past, seeing its pre-colonial era as a pre-civilized limbo or even as a historical void. If the first step towards a postcolonial perspective according to Fanon is to reclaim one's own past, then the second is to begin to erode the colonialist ideology by which that past had been devalued.

By the term post-colonialism, we do not intend or imply in this essay an automatic, nor a seamless and unchanging process of resistance but a series of linkages and articulations without which the process cannot be properly addressed. These linkages and articulations are not always directly oppositional considering the levels of betrayal that have attended the postcolonial societies. The material practices of postcolonial societies may involve a wide range of activities including conceptions and actions which are, or appear to be, complicity with imperial enterprise as we shall argue in the textual analysis of this essay.

In his own argument, Stephen Slemon gives a broader meaning to the term post- colonialism: 
Post-colonialism as it is now used in various fields, describes a remarkably heterogeneous set of subject positions, professional fields, and critical enterprises. It has been used as a way of ordering a critique of totalizing forms for a retooled notion of class", as a subset of both post modernism and post structuralism (and conversely, as the condition from which those who structures of cultural logic and cultural critique themselves are seen to emerge); as the name for a condition of nativist longing in post-independence national groupings; as a cultural marker of non-residency for a third-world intellectual cadre... (168).

We seek to demonstrate here by asking whether literary resistance is in fact necessarily embedded in the representational technologies of those literary and social texts whose structures and whose referential codes they seek to oppose. This question sounds like definitional problem, but we think in fact that they are critical ones for a critical industry, which the present research seems to suggest in its two central themes; post colonial and resistance. Arun Mukherjee makes this point with great dexterity by asking what specificity, what residual grouping, remains with the term 'post colonial' when it is applied, indiscriminately to both Second and Third World literary texts,(18). The term resistance recently found itself at the centre of a similar controversy, when it was discovered how very thoroughly a failure in 
resistance characterized some of the earlier political writings of some great Third World writers, hence our inclusion of politics in the present research in order to justify the intricacies that are at play in postcolonial discourse.

In line with the above, it is pertinent to note that the state in post-colonial Africa is not properly structured to undertake development tasks. This is evident going by the ways and manners many governments in postcolonial Africa would readily and gladly entrust the welfare of their people to the so-called international development agencies, particularly the specialized United Nations agencies and non-governmental organization (NGOs). It is also instructive to observe that even where a political commitment and will to development is evident, as in the case of Nyerere's Tanzania, the colonially-inherited structures of the economy and the state act as an obstacle to development, together with the class forces whose interests they promote.

Like the colonial state, the post-colonial state is a regressive mechanism in charge of an export-orientated economy that serves primarily those who manage it and their trading and other business partners in the developed countries, at the expense of the welfare of ordinary people. In the words of Franz Fanon:

The national middle class that takes over power at the end of the colonial regime is an under-developed middle class. It has practically no economic power, and in any 
case it is in no way commensurate with the bourgeoisie of the mother country which it hopes to replace. In its willful narcissism, the national middle class is easily convinced that it can advantageously replace the middle class of the mother country... keep in the running and to be part of the racket. (119-20)

Inasmuch as the research is basically a study of the relationship between the national liberation struggle and the class struggle, or the interplay between resistance and counter- resistance in post-colonial Africa, it is mainly concerned with analyzing the class contradictions inherent in the struggle of the African people for liberation and development in an attempt to illuminate the nature and basic dynamics of contemporary African politics. All over the continent, the anti-colonial struggle was a great event in the lives of the African people. Both the masses and their petit-bourgeois nationalist leaders expected a lot from it. The masses had hoped that their living conditions would improve as a result of what they saw as a revolutionary experience, and this was in fact what their leaders promised them. But the promise was not honoured after independence, for many reasons, one of which was the fact that the anti-colonial struggle had masked the class contradictions between the petitbourgeoisie and ordinary people. These contradictions became manifest after independence when instead of fulfilling their promises, the new rulers responded to the people's demand either with more promises or with repression. 
In this respect of the class contradictions in the struggle for liberation and development in Africa, we would like to assess the role of African writers' vis-à-vis the resistance and counter-resistance dialectics, and to appeal to those among them who desire radical social change to get involved in the historical process of achieving it. Among those is the author whose works is the central point of our textual analysis in this research. To assist the struggle for political change in Africa, Ngugi wa Thiong'o has gone beyond university campuses to join those social forces opposed to the neocolonial state. Ngugi has therefore joined the popular struggle for radical change by accepting the challenge posed to all of us by Amilcar Cabral to become revolutionary workers.

Most African writers have tended to draw their materials from past and continuing history of their people and have shown their concern for or commitment to the aspirations of their people. Their commitment could be limited to the affairs of their countries as Achebe, La Guma, Ngugi (except Wizard of the Crow) and Ekwensi have done to the affairs of the continent as Armah, Ousmane have done in Two Thousand Seasons and Gods Bits of Wood respectively. This suggests that their writings can be nationalist in orientation, pan-Africanist, or both. They equally champion the cause of their people against threats coming from outside. Their commitment could also go beyond merely depicting the harshness of man's environment and his absurd conditions to suggesting a radical solution to the situation they have identified. This suggests therefore that commitment 
tends to be preoccupied with policies and the discourse is heavily political writings.

This research attempts to investigate Ngugi's concern and perspectives on Africa's march towards genuine statehood and independence. The focus on Ngugi and particularly this very novel becomes increasingly important given the rampaging effects of imperialism and dictatorship on African soil, and the need for political struggle and consequent liberation of the people.

This novel which may well be considered as the hallmark or watershed of Ngugi's writing depicts in its deepest sense the various political, economic and social intricacies that have conditioned and plagued the postcolonial African States' quest towards real development. Ngugi is at his best in the use of metaphysics which he has to a very great extent, succeeded in introducing into the resistance theme of African literature. Coupled with this is the incisiveness and the exposure of the leadership personalities in postcolonial Africa.

Though the novel casts serious aspersions in satirical mode on the internal build-up and the effect of external collaboration of the West in the impoverishment of the African masses, it aptly reflects with great efforts the roles of sycophants in the destruction of African States. This novel, which is arguably, the most voluminous and ambitious novel ever written by an African writer is 
divided into six books that reflect deeply the various intricacies in the governance of African people and how informed and conscious people have equally risen to resist and oppose the draconian rule of dictatorship and oppressive regime. The weakness and ineffectiveness of leadership in Africa is highly exposed with the dictatorial and oppressive tendency of most African governments showcased. Our rulers as we shall soon see have refused to quit the stage even when there is practically nothing for them to offer the people again.

Wizard of the Crow is set in the fictional Free Republic of Aburiria. For as long as anyone can remember, the country has been under the dictatorship of one known simply as the Ruler. The Ruler is a combination of Idi Amin, Mobutu Sese Seko and Pere Ubu, a larger-thanlife figure (this is played out literally and hilariously late in the novel), whose Machiavellian grip on power is so absolute that his ministers trip over each other offering up slavish praises.

The Ruler's cult of personality is so strong that he is often placed on the same level as God, and as frequently chanted throughout the novel. The Ruler and the country are one and the same. Anyone who even vaguely questions his omnipotence is quickly fed to crocodiles 'Is there a distinction between me and the country... who doesn't know that you and the country are one and the same' (136). 
At the beginning of the novel, a huge crowd convenes to celebrate the Ruler's birthday and at the ceremony his sycophantic ministers, in an effort to out-do one another, escalate the national tribute to their leader to the point where it is proposed that a structure be built similar to the Tower of Babel, called Marching to Heaven: This will allow the Ruler to be closer to God 'The Ruler would be the daily recipient of God's advice, resulting in a rapid growth of Aburiria to the heights never before dreamt by humans'(16).

This system, which dissolved into crisis in the 1980s and endured till the 1990s in most African states, is purposeful for the sustenance of power as it demands loyalty from the citizens. Such loyalties are mandatorily expressed in support marches, assemblies of applaud touring dignitaries, purchase of party cards, display of the presidential portrait, participation in plebiscitary elections etc. this kind of patrimonial autocracy and loyalty in the postcolonial Africa state is captured in the rapturous encomium to Mobutu of Zaire by his then interior Minister, Egulu Beanga in 1975:

In our religion, we have our own theologians. And at all times, there are prophets. Why not today? God has sent a great prophet, our prestigious Guide Mobutu. This prophet is our liberator our messiah. Our church is the MPR (political party). Its chief is Mobutu; we respect him like one respect Pope. Our gospel is Mobutism. This is why the crufixes must be replaced by the image of our Messiah. And 
party militants will want to place at its side his glorious mother, Mama Yemo, who gave birth to such son. (Young, 2004:35)

This is a classical example of some of the sycophantic excesses in postcolonial Africa. The Ruler is pleased by this excess, but loan will have to be secured from the Global Bank (IMF and World Bank) to make the project a reality and this provokes the chains of resistance throughout the novel starting from the birthday celebration. The people's aversion to the project is highly reflected, the gloom and silence that follow Machokali's speech, is an evidence of the people's mild resistance to such white elephant projects that have dominated most postcolonial African states:

Except for members of parliament, cabinet ministers, officials of the Ruler's party, and representatives of the armed forces, nobody clapped ...Are you so overwhelmed by happiness that you are lost for words? Is there no one able to express his joy in words? (17)

From the above scenario, people's disenchantment with the regime of the Ruler is highly depicted. In postcolonial Africa, most governments abandon peopleoriented projects for frivolous projects that do not have any significant impact on the people's lives. This pitches some of these regimes with the revolutionary masses who will stop at nothing until they overcome the oppressive regimes across African states. The disruption 
of the birthday celebration when the Ruler is presenting his speech by some revolutionaries shows people's aversion to the whole process and to his regime thus 'this might be the beginning of a coup d'état, and within seconds the Ruler was on his way to the State House' (22).

When we first encounter Kamiti, the co-arrow head of the resistance, he is lying on a garbage heap, having an out-of-body experience as a bird. Trash collectors mistake him for a corpse and are terrified when the dead apparently arises. This sets off a chain of events that will lead to many changes in Aburiria. Kamiti needs a job; having armed himself with a master degree goes into the Eldares Modern Construction and Real Estate Company where he encounters the beautiful Grace Nyawira who later turns out to be the arrow head of the Movement for the Voice of the People.

As we will soon find out, Kamiti and Nyawira are soul mates in sorcery, and their relationship will begin the process of change in Aburiria. As their powers which they utilize so much in resisting bad governance and policies especially the Marching to Heaven project grow, the envy and the wrath of the Ruler will focus on them. Over the course of the novel which is presented through six books as earlier mentioned, a queuing mania will occur which demonstrates and reflects the decaying nature of the Aburirian societies. A condition called white-ache will be cured with mirrors (mirrors and their self- reflecting nature play a very important role in this novel). The novel is full of episodes of surreal magic and 
Brechtian exaggeration, which makes the novel look like a fantasy, but it is pertinent to know that the fantasy is well grounded in the stark reality of the postcolonial Africa which makes it a very complex allegorical depiction of African societies.

As the narrative unfolds, Kamiti who could not find a job decides to become a beggar at the high rise hotels in the city of Eldares. Incidentally, the resistance group (The Movement of the Voice of the People) is using begging as one of their resistance strategies. This compounds the problems of the Ruler because of the subtle approach adopted by this group. Kamiti thus becomes real beggars to resist the Rulers policies:

There were always beggars loitering around those kinds of hotels at all hours of day and night. But that night they were there in unusually large numbers, looking for the entire world to see like wretchedness itself. The blind seemed blinder than usual, the hunchbacked hunched lower, and those missing legs or hands acted as if deprived of other limbs. The way they carried themselves was as if they thought the Global Bank had come to appreciate and even honour their plight. (73-74).

This scenario is created during the visit of the Global Bank officials to Aburiria to assess the feasibility and the viability of the Marching to Heaven project before 
granting the loan or agreeing to finance it. This tends to validate the fact that World Bank, IMF and other financial institutions in the West have collaborated heavily with postcolonial African leaders to further pauperize the masses through their financial support in form of loans to bogus and anti-people projects. This makes the foreign journalists that have accompanied the Global Bank officials to focus their attention on the beggars for they reason that no news from Africa is complete without poverty:

The foreign journalist were particularly interested in the scene, for they believed that a news story from Africa without pictures of people dying from wretched poverty, famine, or ethnic warfare could not possibly be interesting to their audience back home (74).

With this belief, the real intention of the fake beggars is brought into focus through their revolutionary songs and slogans. This strategy is informed by the fact that this is evidently the only way they could attract media attention as a result of their underground movement. Their slogans not only cast serious aspersions on the role of the West in even contemplating granting of loan to the government but trying to hold them responsible for all the many woes of postcolonial Africa through questionable and fictitious loans:

Marching to Heaven is Marching to Hell.

Your Strings of Loans are Chains of Slavery.

Your Loans are the Cause of Begging. We 
Beggars beg the end of Begging. The March to Heaven is led by Dangerous Snakes (74). (86).

These slogans in form of song make the beggars to be suspected and they were subsequently dispersed before they could cause further damage to the image of the Ruler before the international media.

As stated earlier, Kamiti, the poor job seeker, inadvertently becomes involved in a protest by the underground Movement for the Voice of the People during a visit by a delegation from the Global Bank. During their dispersion by the police, Kamiti, along with the mysterious female leader of the movement, Nyawira, finds himself running for his life chased by policemen. Hiding out in Nyawira's house, he comes up with the ingenious notion of posting a sign claiming the property is inhabited by a powerful sorcerer in order to frighten the pursuers away. The novel derives its title from this very action and almost all the actions in the novel are premised on this:

The other beggar tied the bones and rags together. He then took a felt pen from his bag and wrote on the cardboard in big letters: WARNING! THIS PROPERTY BELONGS TO A WIZARD WHOSE POWER BRINGS DOWN HAWKS AND CROWS FROM THE SKY. TOUCH THIS HOUSE AT YOUR PERIL. SGD WIZARD OF THE CROW. (77) 
In a world that seems hopeless, magic provides the only possibility of hope. But what at first appear to be all smoke and mirrors, plus a basic understanding of human psychology, soon have both Kamiti and Nyawira wondering if Kamiti does indeed have magical powers. During a trip home to his family's village, Kamiti's father reveals that Kamiti comes from a long line of sorcerers. When a corrupt businessman loses the power of speech, the Wizard diagnoses it as a case of "whiteache", the yearning to be European.

It is pertinent to note here that part of the problems and the causes of great underdevelopments that are visibly evident throughout postcolonial African states are reflected in the above passage. The government is not interested in the people-oriented projects and policies but for the aggrandizement of their interest. The government is least ready financially to undertake this worthless project, but ready with the connivance of the West to get loans and further pauperize the masses.

The contrast between Aburirians decaying cities and Marching to Heaven's pointless extravagance and the wealthy Aburirian dignitaries who figure to profit from it is ripe:

One was made up of people in custom suits, standing stiffly and solemnly as if at a fashion parade; it reached all the way to the door... The second line started at the billboard TEMPA JOBS: APPLY IN PERSON... 
which as Nyawira later learned, had sparked a rumour that the chairman was hiring thousands of workers for Marching to Heaven (138-139)

Just as the Ruler begins trying to present a good image to the Westerners who hold the fate of his super wonder project in their hands, the dissident Nyawira's Movement for the Voice of the People begins to emerge as a thorn in his flesh. They vow to:

...oppose the Ruler's birthday cake and the Global Bank mission of putting us in a permanent debt trap. We must all oppose this business of Marching to Heaven (86).

As a result of opposition coming from this underground movement, the funds from the global bank are not forthcoming and eventually the Ruler decides to go on a diplomatic mission to shore up the support from the international communities for his project and subsequently becomes absurdly pregnant:

The chance to go to New York to be wined and dined while lobbying for support for marching to Heaven was medicine to the Ruler's wounded soul (243).

Yet just when it looks like the poverty, rebellions and runway violence will bring the Ruler's reign to a close, he manages to escape and birth 'Baby D' democracy. This is a multiparty system in which the Ruler 
automatically becomes head of whatever party receives the highest votes:

...but he added that the new Aburirian system was only making explicit what was latent in all modern democracies, in which parties were basically variations of each other. He would be the nominal head of all political parties... (698-699)

This makes those who would forge a cause for a reformed and changed Aburiria to go back to square one (233-234. 701 724)

Wizard of the Crow is a breakthrough because it drills down deep into the heart of how politics gets done, the Ruler ordering his subordinates about and sowing the seed of discord:

The dictator's reputation for making minister plot against minister, region against region, and community fight against community was now a matter of legend...would be would be embraced by all the feuding parties as a Solomonic prince of peace (231).

This is the main political strategy of the Ruler to remain firmly in control of power. This is also the strategy employed by most contemporary African Rulers to hold on to power despite serious resentment from the populace. This is highly enhanced by the subordinates' 
own machinations, the deals made by leaders of Aburirian's business community, the rise of upstarts in government like Kaniuri and the methods of the resistance. Ngugi takes us to the atomic level, showing us how politics happens in Aburiria on a person-byperson basis. And in all these transactions and incidents, exaggerated storytelling and rumours is the central key to their development.

This storytelling exemplifies the techniques and the architecture used by political actors in Aburiria as they continually invent tales that, with breathtaking speed, become the new realities that the country must live by. These realities include the bizarre things that take place daily in various government houses across post-colonial African States which have greatly undermined the developmental desires of the masses. Whether it is the Ruler purposefully creating realities with an iron hand or the businessmen doing it in ignorance as they arrange deals or the masses supporting the oppressive regime without realizing it:

Each card was handed over with thousands of Buns. A few dignitaries had tried to write checks, but Tajirika would not hear of it, cash or nothing, Tajirika told them, and they were quick to say that they completely understood. A few insisted on a business luncheon appointment, adding even more Buns with their cards. (104). 
This also applies to even the resistance movements innocently slipping into stories that help them toward their goals, the creation of stories remain central to the plot development:

Can you believe it? Outside gates of the state House, under the very noses of the police and the soldiers guarding the palace! The question is, how did the pamphleteers get inside these heavily guarded locations without detection? (127)

The act of ignorantly and innocently promoting the resistance movement without realizing the essence and the efficacy of their action is captured in the queuing scene outside Eldares Construction and Estate Company. The refusal of the queue to disappear creates a very serious problem for the ruler and his ministers who attempt and decide to use the queue to their advantages:
And now a sight even more amazing unfolded. When those at the head of the queue read the notice and broke the news, those immediately behind them refused to believe their ears ...no seeing this apparent movement, would rejoin the queues at the rear, Queues without an end (141)

The government not knowing what to do with the queues of the jobless and unemployed Aburirians decides to 
reverse the essence of the queues to their advantage; because the Ruler initially is worried:

It became obvious, at the emergency session at the State House, that what most concerned the Ruler was the crazed rider's observation that the queues seemed to have no beginning and no end. That sounds dangerous, doesn't it? (159).

\section{Conclusion}

From what we have said so far, it is evidently clear that most of the problems facing African continent have strong rooting in the relationship between the leaders and their imperial lords in the West.

In Wizard of the Crow, Ngugi continues with his position on what should be the role of the masses in opposing tyrannical rules in the continent. For the first time in his entire literary career Ngugi gives a broader setting to reflect what is common to many African states as opposed to his customary Kenyan settings. In the introduction to this essay we discuss how many governments across Africa have delegated their responsibilities and duties to foreign donors and NGOs. This is made evident in Wizard of the Crow where major projects of the government rely solely on the approval of financial institutions from the West. Their (West) interest is the first consideration before the masses' interest. The opposition to this postcolonial or neocolonial system is what we have traced in this paper, which makes it convenient for us to align ourselves with 
the position of Ngugi over the years. His call for total opposition and resistance against neo colonial system has been given great credence considering the recent political upheavals in his native country Kenya. As a result of people's resolve to fight for their right in what has been termed globally as "Kenyan Option", constitution amendment was made possible forcing the tyrannical government to cede power to the opposition. This has greatly justified our position in this essay and the approach of total resistance against oppression regimes in Africa. Kenya's example has therefore served as frontier for other oppressed masses across Africa, that they will achieve what was achieved though belated, if they can rise up and challenge the status quo. This is exactly what happens in Wizard of the Crow where the masses directly and indirectly frustrate government oppressive policies and thereby causing a change of government despite the fact that it is also belated, we therefore believe that, African total emancipation is and should be a gradual process.

The paper therefore, concludes that for Africa to experience the bliss of political, economic and social stability Ngugi's efforts and viewpoints on what should be true position and nature of the resistance culture of the peasants must be appreciated and embraced.

Maxwell 'Dele Ugwuanyi is of Caritas University, Amorji, Nike. Enugu, Nigeria. 


\section{Works Cited}

Ade-Ajayi, J.F. 'Expectation of Independence' in Daedalus. vol. 111, no. 2. 1982. 11-125

Amilcar, Cabral. Unity and Struggle: Speeches and Writings New York: Monthly Review Press. 1979.

Balogun, Odun F. Ngugi and African Postcolonial Narrative. Quebec: World Heritage Press. 1997.

Bill, Ascroft, et al. The Empire Writes Back; Theory and Practice in Postcolonial Literature. London: Routledge. 1995.

Crawford, Young.. Ideology and Development in Africa; New Haven: Yale University press, 1982

Dasylva, Ademola. "The Writer and Phases of Conflicts in Africa" in UFAHAMU: A Journal of African Studies. Volume xxxi no iii. , 2005. 95-116

Fanon, Frantz. The Wretched of the Earth. Middlesex: Penguin Books. 1965.

Kofi, Anyidoho. "Art in a Society in Transition" in African Quarterly on the Arts. Vol. 11 No.4. 1999. 60-72

Llosa, Maria Vargas. "Social Commitment and the Latin America Writer" World Literature Today 52 (winter 1978)

Mukherjee, Arun P. 'Whose Post-colonialism and whose post-modernism?' World Literature Written in English vol. 30 no. 2. 1990. 55-71.

Ngugi wa Thiong'o. Wizard of the Crow. Lagos: Farafina.. 2007.

------ Moving the Centre: The Struggle For Cultural Freedom. London: Heinemann. 1993. 
Nzongola-Ntalaja, Georges. Revolution and CounterRevolution in Africa: Essays on Contemporary Politics: London: Zed Books. 1987.

Ogude, James. Ngugi 's Novels and African History. Sterling: Pluto Press. 1999.

Pandurang, Mala. "Ngugi wa Thiong'o: A Bio-literary Perspective" in Ngugi wa Thiong 'o: An Anthology of Recent Criticism. New Delhi: Pencraft International. 2007.

Slemon, Stephen: 'The Scramble for post-colonialism' in Chris Tiffin and Alan Lawson (eds) De-Scribing Empire: Post-colonialism and Textuality London: Routledge. 1994.

Swingewood, Alan. The Novel and Revolution New York: Harper and Row Publishers Inc., 1995.

Young, Crawford. "The End of the Postcolonial State in Africa? Reflection on Changing African Political Dynamics" in African Affairs: 103, 2004. 33-47.

Young, Robert. Postcolonialism: A Very Short Introduction. Oxford: Oxford University Press. , 2003.

Young, Robert. Postcolonialism; A Very Short Introduction. Oxford: Oxford University Press. 2003. 